Article

\title{
Carpe Diem: Love, Resistance to Authority, and the Necessity of Choice in Andrew Marvell and Elizabeth Cary
}

\author{
Michael Bryson (1) \\ Department of English, California State University, Northridge, Northridge, CA 91330, USA; \\ michael.bryson@csun.edu
}

Received: 13 April 2018; Accepted: 11 June 2018; Published: 14 June 2018

\begin{abstract}
The theme of love as resistance to authority is the centerpiece of a two-millennia-long tradition in Western poetry known as carpe diem (a phrase credited to the Latin poet Horace). This essay begins by analyzing one of the most famous later examples of carpe diem in English poetry (Andrew Marvell's 1681 "To His Coy Mistress"), emphasizing the carpe diem ethos' potential to illustrate both the consequences and the necessity of individual erotic choice-especially female choice-in defiance of authority. It then uses carpe diem's anti-authoritarian perspective to understand the contrast between the ambivalence of Mariam - torn between a tepid disobedience and regretful loyalty to her husband Herod - and the wholly defiant choices of Salome in Elizabeth Cary's earlier drama, The Tragedy of Mariam from 1613.
\end{abstract}

Keywords: love; choice; carpe diem; resistance; authority; poetry

\section{Introduction}

Carpe diem poetry, a tradition dating back to the Augustan era in Rome, presents a worldview that seems filled with a sense of the fragility and shortness of life; but at its essence, it is concerned with individual choice in a world that often attempts to circumscribe, or even eliminate, the possibility of such choice. It takes its name from a phrase by the "Latin poet Horace, who in Ode, I. xi, tells his mistress that [...] life is short, so they must 'enjoy the day,' for they do not know if there will be a tomorrow" (Glancy 2002, p. 43). Horace lives and works in an increasingly authoritarian Rome in which the passing of such laws as the Lex Iulia de Maritandis Ordinibus and the Lex Iulia de Adulteriis Coercendis (of 18 and $17 \mathrm{BCE}$ ) represented an ongoing attempt to use the power of government to "reform Roman private morality." In such an environment, Horace's line, "carpe diem quam minimum credula postero" (Horace 1998, p. 39) — "Seize the day, trusting as little in the next as possible"2 —has a political resonance, as it tells Leuconoe, and all who have followed since, to live now, and love now, despite the demands of authority, because each second of scruple, doubt, and delay brings men and women closer to a death that is non-negotiable, non-delayable, and everlasting. The carpe diem ethos informs works as diverse as the fourth-century (CE) Latin poetry of Ausonius, ${ }^{3}$ to the troubadour poems of the eleventh and twelfth centuries, to the plays of Shakespeare and the poetry of John Donne and Robert Herrick. It appears, perhaps most powerfully and famously in Andrew Marvell's 1681

\footnotetext{
These laws proscribed class intermarriage, and fornication/adultery respectively (Davis 1999, p. 435).

All translations in this essay are my own.

The final two lines of "Ad Uxorem" beautifully capture the idea of living for now: "nos ignoremus quid sit matura senectus: /scire aevi meritum, non numerare decet" [let us be ignorant of maturity and age, /and know Time's worth, not count its years]. "Ad Uxorem", Epigram 20. (Ausonius 2001, p. 45)
} 
poem, "To His Coy Mistress," 4 where the idea of death becomes life's and love's greatest ally in the battle against the demands of authority, convention, and law. No less powerfully, if less famously, carpe diem plays a central role in Elizabeth Cary's 1613 drama, The Tragedy of Mariam, in the context of a radical assertion of female freedom that insists on the necessity of choice in love and desire as resistance to authority.

Reading each work in relation to the other, even through the other, can give us very different perspectives than we might otherwise have. ${ }^{5}$ Despite its later composition, Marvell's invocation of the long-established ideas of carpe diem poetry can show us something of the temporal urgency Salome faces in her decision to leave her husband for another man, and can further illustrate the trap Mariam finds herself in, unable to choose her own desires. Cary's earlier dramatization of the choices both made and not made by her characters can help us envision the less playful side, even the life-and-death gravity, of the choice posed to the "Coy Mistress" of Marvell's poem. Though Cary could not have read "To His Coy Mistress," and Marvell was likely not consulting the text of The Tragedy of Mariam when writing his poem, each work stands-as does the carpe diem ethos itself-in defiance, but also in hope, insisting together, across the years that separate them from each other, and from us, that readers face the necessity of choice.

\section{A Fine and Private Place: Andrew Marvell and His Coy Mistress}

Perhaps after Robert Herrick's "Gather ye rosebuds while ye may," the single line of carpe diem poetry most recognizable to English language readers is "If we had but world enough and time." It is a line, like "To be or not to be, that is the question," or "Better to reign in hell than serve in heaven," that elicits a shock of recognition, each line an example of that "work of genius" Emerson describes, in which "we recognize our own rejected thoughts" coming back to us "with a certain alienated majesty" (Emerson 2002, p. 175). We know, all of us at some level, that we have neither world enough nor time, despite the countless tasks with which we busy ourselves, the deadlines at work, the striving for success, the pursuits of love or knowledge (for academics, that latest paper that must be written), all of the hundreds and thousands of little ways we distract ourselves from the onrush of our mortality. Still, we know, and a line like that which opens Andrew Marvell's "To His Coy Mistress" brings that knowledge right up close, forcing us to pay attention. We all have our coynesses, our defensive refusals to deal with the reality of the absurd and ultimately fatal disease from which all of us suffer; we wish to think (or more precisely "not-think") that we have, if not endless tomorrows, at least so many as allow us to indulge in the time-wasting and death-hastening scruples of our island and tribe and time ${ }^{6}$, throwing off until tomorrow and tomorrow and tomorrow the choices necessary to live as fully as possible in worlds that will, if we let them, lead us like fools to dusty death, worlds that would deny us the chance ever to discover who we really were, and who we might have become. This perhaps most powerful of all the English carpe diem poems, reminds its readers that it is a kind of crime to be quite so coy in the face of the fine and private place to which we are all bound.

Marvell himself was a complicated man, one whom Nigel Smith has recently described as "a poet who denied [...] poetic egotism by a form of studied imitation" through which, as in the present poem, he often exceeded his models (Smith 2010, p. 9). On the other hand, Marvell was also possessed of

4 Published in 1681, though written perhaps as early as 1652 (Smith 2010, p. 37).

5 Though some readers might find it odd to read a literary work through the perspective of a later literary work, fewer seem to object to reading a literary work through the perspective of a later theoretical text. In neither case is the direct influence of the later text on the earlier one being argued for, nor could it be. In both cases, what is crucial is the perspective the pairing gives the reader in his or her encounter with each text.

6 We often have an unfortunate tendency toward "presentism," the assumption that the ways of our now are always superior to the ways of any given then. But as Robert Musil reminds us, our nows and thens are merely accidents: "die Gegenwart sieht stolz auf die Vergangenheit herab, und wenn die Vergangenheit zufällig später gekommen wäre, so würde sie stolz auf die Gegenwart herabsehen" (Musil 1957, p. 469) [the Present looks proudly down upon the Past, and if the Past had chanced to come later, it would look proudly down upon the Present]. 
"a very hot temper" and seems to have been a man "who did not suffer fools gladly [...] and reacted with excessive violence or agitation when frustrated. Contemporaries, albeit hostile critics, saw a man with a sneer. He enjoyed snide laughter at those who deserved to be treated with contempt" (Smith 2010, p. 9). Yet Marvell was also "the most effective political and religious satirist of his day, one of the greatest lyrical and political poets in the English language, and in his time, one of the most advanced thinkers in respect of toleration and free thinking" (Smith 2010, p. 11), and this in an especially authoritarian and unstable mid-seventeenth century in England. The poet, the politician, the man, was (and is) not easy to pin down, not easy to pack tidily away onto one's ideological shelves. As complicated as the man could be, his poetry is perhaps even more complicated, often at odds with itself, moving from voice to contradictory voice with the ease of an observer whose point of view allows him to see all sides of a question at once-as can be seen, for instance, in the Mower poems, which Linda Anderson has described in terms of their split point of view:

all four poems [present] a single individual who defines himself in a special relationship with nature while at the same time hinting that the reader should question that definition. For while the Mower defines himself as a demigodlike figure in an unfallen Eden, Marvell presents him as a childlike figure, unable or unwilling to distinguish between his own desires and reality. (Anderson 1991, p. 131)

This ability to shade perspectives to the point that two different points of view seem possible, even though one standpoint seems the one common sense would have us choose, is evident in "To His Coy Mistress." The speaker of this poem, like Marvell's Mower, "uses his considerable mental powers to recreate an unsatisfactory natural world" (Anderson 1991, p. 131), but the power and urgency with which he expresses his desire and frustration has left some readers, like Nigel Smith, wondering if the poem is "almost [...] self-parodic" (Smith 2010, p. 103), while other readers like Joseph Moldenhauer, have described "To His Coy Mistress" as a work that walks a fine line between seriousness and comedy: "for all its seriousness it is a comic poem, while for all its levity it is deeply serious" (Moldenhauer 1968, p. 205).

Marvell's first stanza captures that blend of seriousness and (exaggerated, though purposeful) humor:

Had we but world enough, and time,

This coyness, lady, were no crime.

We would sit down, and think which way

To walk, and pass our long love's day.

Thou by the Indian Ganges' side

Shouldst rubies find: I by the tide

Of Humber would complain. I would

Love you ten years before the flood:

And you should, if you please, refuse

Till the conversion of the Jews.

My vegetable love should grow

Vaster than empires, and more slow.

An hundred years should go to praise

Thine eyes, and on thy forehead gaze.

Two hundred to adore each breast:

But thirty thousand to the rest.

An age at least to every part,

And the last age should show your heart.

For Lady you deserve this state;

Nor would I love at lower rate.

(Marvell 2003, pp. 81-82, 11. 1-20) 
The obvious purpose for the speaker in these lines is to overcome the "coyness" of the lady. As Moldenhauer observes, "the poem presents a distinct dramatic and rhetorical situation. Its central agon pits the speaker's desire for erotic fulfillment against the hesitancy of his lady" (Moldenhauer 1968 , p. 193). Thus, the conceit behind the first line-as most readers seem almost instinctively to recognize-is that we do not have world enough and time, if "world enough" is conceived as a space "Vaster than empires" and time enough is defined as the hundreds, thousands, even tens of thousands of years the first stanza describes. If we had such vast stretches of world and time, the speaker argues, then the lady's coyness, her noncommittal delay, would be just fine (though one senses that it really wouldn't be fine with the speaker, but at least there would be sufficient time to praise and persuade). In a situation of endless time and space, the speaker and his lady could wander the world separately, she by the exotic Ganges river in India, while he was stuck with the rather more prosaic Humber river in England. He can even imagine stretching time backward and forward, so elastic, relaxed, and unurgent is the quality of time within a span of all-but-eternity. His love for her could then be extended back into the ancient past ("ten years before the flood") and off into the unchartable future (in which case she could "refuse/Till the conversion of the Jews" - an event, that as Nigel Smith points out, was associated in the mid-seventeenth century with the millennium to come after the end of the world (Smith 2010, pp. 104-5). With such temporal plenitude on their hands, the speaker could (or so he claims) spend "An hundred years" on praising the lady's eyes (though it seems that fifty years per eye would eventually leave even so poetic a speaker as Marvell's at a loss for words, and both he and his lady suffering from a massive case of boredom). Even more spectacularly (or horrifyingly, depending on your point of view), the speaker claims that he would spend two hundred years praising each of his lady's breasts, and thirty thousand years on the unspecified "rest" (undoubtedly including the very regions he hopes to have access to at some point before the end of the world).

But-and a sensitive reader has been waiting for that shoe to drop since the very first line-we do not have eternity, and we do not have "the world" as Shakespeare's Richard III says, "to bustle in" (Richard III, 1.1.160.). ${ }^{7}$ Life is short, and with each year, each day, each breath, death is closer than ever before:
But at my back I always hear
Time's wingèd chariot hurrying near;
And yonder all before us lie
Deserts of vast eternity.
Thy beauty shall no more be found;
Nor, in thy marble vault, shall sound
My echoing song: then worms shall try
That long-preserved virginity:
And your quaint honour turn to dust;
And into ashes all my lust.
The grave's a fine and private place,
But none I think do there embrace.
(Marvell 2003, pp. 82-83, 11. 21-32)

Time is both relentless and violent—-the "wingèd chariot" references the Merkabah, the winged chariot-throne of Yahweh from Ezekiel chapter 1, and the chariot with which the sun-god Apollo drags the sun across the sky, as well as the familiar battle chariots of the Biblical Egyptians and Philistines, and even the anger of Yahweh against his own people:

7 Quotations from the plays are from (Shakespeare 2002). 


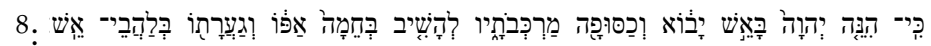

For behold, Yahweh will come in fire, like a raging storm with his chariots, to render with fury his anger and his rebuke in flames of fire.

Once that chariot catches up with us, the speaker says, all that waits for us is the nothing and never of King Lear, the "Deserts of vast eternity." And despite the claims of a poem like Shakespeare's sonnet 15, in which the poet fights a "war with Time" (line 13) to preserve the beauty of the young man being addressed, Marvell's poem will promise no such warfare and no such preservation: "Thy beauty shall no more be found," either in the world, or in "My echoing song," which you, lady, will not be able to hear anyway, sealed away in "thy marble vault."

And then, the poem turns almost ghastly, forcing our attention-and presumably the lady's attention - to the physical details of death and decay. We will be, as Hamlet says, "at supper," where "a certain convocation of politic worms" (Hamlet 4.3.18-20) will be at us like famine victims at a banquet table. Let the worms "try/That long-preserved virginity" says the speaker, in what seems a suddenly bitter tone. You'd rather have them inside you than me? Because you will have them inside of you one day, soon, and without your permission. Coyness may work with me, but it won't work with the worms. It seems almost as if the speaker has here, rather like Hamlet in the scene with Ophelia right after the famous "To be or not to be" speech of 3.1, allowed himself to get so frustrated and even angry that he has forgotten to play his role-madness for Hamlet, smooth persuasive charm for Marvell's speaker. The focus on the undeniably grotesque details of decomposition knocks the speaker off track here, as he seems almost to denounce the lady he would persuade. He rails at her, telling her that her "quaint honor" (honor that is both old-fashioned, and concerned with the body part Chaucer refers to as the "queynt") will turn to dust, or whatever might be the term for the waste product that emerges from the alimentary canals of worms, while his lust-desire, life-will end up as nothing more than ashes. The powerful final couplet, however, is the payoff for the anger and grotesquerie that precedes it-in the grave, where speaker, lady, readers, everyone ends up, no one any longer has world enough or time enough for love: "The grave's a fine and private place, / But none, I think, do there embrace." The wry, ironic, perhaps even sarcastic "I think" seems to say to the lady (and any reader on the path of asceticism, denial, or even delay) what are you thinking? The time for life and love is now, because we have eternity to be alone, and chaste, in our graves.

The final stanza returns to gentler persuasion, but this time with an enhanced urgency. The time is now:

Now, therefore, while the youthful glew

Sits on thy skin like morning dew,

And while thy willing soul transpires

At every pore with instant fires,

Now let us sport us while we may;

And now, like am'rous birds of prey,

Rather at once our Time devour,

Than languish in his slow-chapped power.

Let us roll all our strength, and all

Our sweetness, up into one ball:

And tear our pleasures with rough strife,

Through the iron gates of life.

Thus, though we cannot make our sun

Stand still, yet we will make him run.

(Marvell 2003, pp. 83-84, 11. 33-47)

8 Isaiah 66:15. Biblical text is quoted from Biblia Hebraica Stuttgartensia (Rudolph and Elliger 1983). 
Now, while you are young, and while you are both willing and able (as your "willing soul transpires" or emits "instant fires" from "every pore" - either the speaker is trying to persuade the lady here, or she is more willing, even aroused, than she has so far let on), now let us "sport us" and like "amorous birds of prey" tear into the meat of life and love, devour Time itself rather than passively waiting for it to devour us. Let us not be kept out, barred, and excluded by the iron gates of life-gates of the kind meant, not to keep people in but to keep them out, in this case, the kinds of laws, customs, and social restrictions designed to keep them, and other lovers, out of the realms of pleasure and delight, limitations akin to what William Blake calls the "mind forg'd manacles" (Blake 1893, p. 56), the internalized rules that keep us from living fully, rules that exist only in the minds of all those who refuse, or are too terrified to say no to their arbitrary demands. If we are to live so, we will have to "tear our pleasures with rough strife/Through the iron gates of life," because as Frederick Douglass observes "Power concedes nothing without a demand. It never did and it never will" (Douglass 2000, p. 367). The gods and kings of the world, with their theological, legal, and economic demands, will keep those "iron gates of life" barred at all costs, and the only resistance that has any chance at all of being effective is love. And even that resistance is ultimately futile, for "we cannot make our sun/Stand still." We cannot stop the relentless march of time and the rapid approach of death. But we can "make him run." We can live life as fully as possible, and dare the sun, dare Time, dare Death to catch us.

It should go without remarking that the lady does not respond, so we have no clear sense of what, if anything, the coy lady addressed by the speaker thinks of his persuasions. And the critical reaction reflects a wide range of viewpoints. Thomas Wheeler argues that "To His Coy Mistress" is "the least Marvellian of all his poems" (Wheeler 1996, p. 90). He grounds this contention in the idea that Marvell's most famous poem "fits perfectly into an identifiable poetic tradition. The carpe diem theme received memorable treatment from Marlowe, Donne, Jonson, Herrick, and Carew. Marvell's poem only stands out because of its grim vision of the grave and its passionate urging of the lovers' case. In other words, it does what a typical carpe diem poem does, but it does so with unparalleled power" (Wheeler 1996, p. 90). Wheeler seems to think that "To His Coy Mistress" is un-Marvellian because it is, in its genre and form, unoriginal. But a critic like Nigel Smith argues that such "imitation" is a Marvellian trait, since the poet "made a virtue and indeed a highly creative resource of being other men's (and women's) mirrors" (Smith 2010, p. 9).

A rather more radical response to "His Coy Mistress" is found in Bernard Duyfhuizen, who insists that the poem has been read through the terms of "Masculine Criticism" for far too long, and describes Marvell's poem as a "demeaning seduction" that depends on its "metaphysical conceit" to raise it "to the level of high seriousness as a universal construct of man's desire to conquer his own mortality" (Duyfhuizen 1988, p. 418). Duyfhuizen identifies what he calls "a phallic causality" in the poem, one that "merely rewrites, rather than frees the Coy Mistress" (Duyfhuizen 1988, p. 418), and argues for a "feminist reading" which highlights the "noncapitulation of the Coy Mistress to her ardent Cavalier" (Duyfhuizen 1988, p. 421). But in positing a "plot of her refusal of love [and] her conviction to love only on her terms" (Duyfhuizen 1988, p. 419), Duyfhuizen rewrites the poem according to his own ideological commitments, providing a response that Marvell's poem does not contain. In the process, Duyfhuizen tells us more about himself than about the poem. Duyfhuizen's reading is driven by near-constant negative framings of anything he associates with the "male" or the "masculine"-for example, the "male theme and plot of conquest" (Duyfhuizen 1988, p. 413) is assumed to be both pervasive in poetry, and unsurprisingly, akin to "rape" (Duyfhuizen 1988, p. 413).

For Duyfhuizen, the "'iron gates of life' represent the hymenal barrier the speaker seeks to break, but it [sic] also represents the birth canal [ ... ]. In the male plot the gates are thrown open to welcome lust and life, but in the female plot the gates may be slamming shut" (Duyfhuizen 1988, p. 421) If "iron gates" are to be taken seriously as a "vaginal metaphor" (Duyfhuizen 1988, p. 419) one wonders exactly how any human reproduction ever takes place. Iron vaginas do not sound like particularly welcoming places, either for adult visitors or for fetal travelers. The critic then goes on to express his 
grave concern that "the female reader" (as if there is an easy, universal definition thereof) must resist being seduced into "reading like a man" (Duyfhuizen 1988, p. 416), which raises the amusing question of whether such a "female reader" (as defined by a man named Duyfhuizen) must resist his masculine definition of them as females and as readers, at which point the entire argument threatens to reveal itself as parody.

A more helpful perspective on the poem is offered by Catherine Belsey, who suggests a political context and purpose for the poem when she argues that "To his Coy Mistress" may have been "drafted in 1649, the year when the execution of Charles I emblematically established the end of the old order of sovereignty and subjection" (Belsey 1987, p. 105). Belsey goes on to argue that "[i]n innumerable Renaissance poems, daffodils, roses, dew, snow, spring and all of nature conspire to demonstrate the worth of things that perish. The imminence and the eternity of death makes sex more urgent, its pleasures more intense. The body is precious because it dies" (Belsey 1987, p. 112). And it is the very worthiness and value of the mortal, the soon-to-die, which gives Marvell's poem its power: "It is chastity, not lechery, which is punished after death by worms. [...] To choose love rather than asceticism is to defy eternity and choose the world. [It is] to repudiate the values which promise eternal life; to choose the pleasures of the body is thus to reject immortality" (Belsey 1987, p. 112). Such a choice rejects the demands of gods who offer immortality at the price of submission, a defiant stance we see taken on the epic scale both by Odysseus in the Odyssey, and by Adam and Eve in Milton's Paradise Lost.

But perhaps the most useful point about "To His Coy Mistress" is made in a fifty-year-old article that now seems like a remnant from an entirely different academic era. Rather than attempt to "reveal" or "unveil" anything about Marvell's most famous work, Joseph Moldenhauer simply reminds us not to stray too far from the literary context within which the poem came into being:

Over the exuberance of Elizabethan and seventeenth-century poetry the pall of death continually hovers, and the lyrics of the age would supply a handbook of strategies for the circumvention of decay. The birth of an heir, the preservative balm of memory, the refuge of Christian resignation or Platonic ecstasy - these are some solutions which the poets offer. Another is the artist's ability to immortalize the world's values by means of his verse. [...] The carpe diem lyric proposes are more direct and immediate, if also more temporary, solution to this overwhelming problem[:] the "harmless folly" of sensual enjoyment. (Moldenhauer 1968, pp. 190-91)

For Moldenhauer, what makes the carpe diem mode is "its advocacy for a physical, rather than an aesthetic, solution to the problem of time" (Moldenhauer 1968, p. 204).

Finally, what "To His Coy Mistress" asks its readers to see is that the wages of life are death, and no amount of trying to recuse oneself from the pleasures and pains of life will alter or diminish the payment of those wages by even a jot. Death is coming, and that is the primary reason not to obey the will of another (whether a god or a human ruler), but to choose for oneself whom to love and how to live before that life ends. The poem has undeniable power, and perhaps a great part of that power lies in its call for the lady to make up her mind about life, and its parallel call for its readers to make up their minds about life. The dilemma described by Marvell's poem is remarkably similar in its terms (and its power) to that faced by the narrator of Friedrich Schiller's 1786 poem, "Resignation." Faced with the choice between the pleasures of life now, or the hope of a life to come, Schiller's narrator makes the pious and obedient choice that Marvell's narrator hopes his Coy Mistress will reject. Speaking to der Vergelterin (the Rewarder-the poem's term for God), Schiller's narrator obeys the command to reject the joys of life: 
"Ich zahle dir in einem andern Leben, Gib deine Jugend mir!

Nichts kann ich dir als diese Weisung geben." Ich nahm die Weisung auf das andre Leben, Und meiner Jugend Freuden gab ich ihr. "Gib mir das Weib, so theuer deinem Herzen, Gib deine Laura mir! Jenseits der Gräber wuchern deine Schmerzen." Ich riß sie blutend aus dem wunden Herzen Und weinte laut und gab sie ihr. (Schiller 1873, p. 64)
“I'll pay you in another life,

Give me your youth!

Nothing but this command can I give you." I accepted the command to the other life, And I gave you my youthful joys.

"Give me the woman, so dear to your heart, Give me your Laura!

Beyond the grave you will profit from your pain." I tore her bleeding from my wounded heart, And cried aloud, and gave her to you.

But the sacrifice was a foolish one, as Schiller's narrator is told by der Vergelterin that the sacrifice of life and love had been its own perverse reward, that Hope leads to nothing like the andern Leben that had been promised, and wasted time and opportunities will never be reclaimed:

“Du hast gehofft, dein Lohn ist abgetragen,

Dein Glaube war dein zugewognes Glück.

Du konntest deine Weisen fragen,

Was man von der Minute ausgeschlagen,

Gibt keine Ewigkeit zurück."

(Schiller 1873, p. 66)
"You have had Hope; your wages are paid, Your faith was the happiness weighed out to you. You might have inquired of the wise: What is rejected in the moment, No Eternity gives back."

"To His Coy Mistress" poses a simple choice, and insists on the necessity of choice. Will you live now, will you choose for yourself, as you would if there were no laws-either human or divine, secular or theological-against the joys of life and love? Or will you submit to the will, the laws, the customs, even the whims of authority, as you patiently and obediently wait for death?

\section{Carpe Diem as Will and Choice in Elizabeth Cary's The Tragedy of Mariam}

The questions posed by Marvell's poem, and by the long-established carpe diem theme itself, help us understand what is most powerfully at stake in Elizabeth Cary's 1613 drama The Tragedy of Mariam, the Fair Queen of Jewry. Choice, specifically female choice, is precisely what is at issue in the world Cary portrays. Female will, in a world of male power, and the consequences of choosing other than kings and husbands would have women choose, are central to the dilemmas of both Mariam, the Judean queen who struggles with the question of obedience, and Salome, whom some critics are inclined to dismiss as a libertine and a villain for openly choosing in defiance of the norms of her time and place. To choose, of course, is often more difficult than it sounds. "All choice is frightening, when one thinks about it: a terrifying liberty, unguided by a greater duty." ${ }^{\prime \prime}$ Choices open some doors, but close others. New lives, new possibilities, come at the expense of other possibilities, lives now foreclosed or lost. Authority figures - the insistent Augustus Caesars of the world-often try to simplify matters, insisting that choice must be circumscribed, that only certain choices are allowable or legitimate. In the face of such demands, to seize the day is to choose for oneself, to refuse to submit, to be willing to take the risk of living before that "necessary end" (Julius Caesar 2.2.36) finally comes.

From the perspective of authority, however, the key function of choice is to elicit praise for one's obedience, praise delivered by the very authority figure who takes pleasure in being obeyed. Choice in the ruled, which includes the possibility of disobedience, enhances the pleasures of power for the ruler. Subjects without choice, without free will, or with wills so broken as to be no longer functional, offer the ruler no satisfaction: "what pleasure I, from such obedience paid?" (Milton 1957, Paradise Lost 3.107). The pleasure stems from the experience of an active and functioning will submitting to one's

9 “Tout choix est effrayant, quand on y songe: effrayante une liberté que ne guide plus un devoir" (Gide 1921, p. 14). 
own. In the case of those who choose incorrectly, those who disobey, such a ruler inflicts punishment, up to and including death. But the political point of carpe diem poetry, from the Odes of Horace to Marvell's "To His Coy Mistress," is that such rulers are absurd and to be defied, because death is coming anyway. Thus, the question is not if one will eventually die, but if one will live first, and that stark reality is the ground on which the battles over choice are fought in The Tragedy of Mariam.

The play's king, Herod, is precisely the kind of authority figure for whom the necessary consequence of incorrect choice (the choice to follow one's own will rather than that of the ruler) is death. Furious with Mariam, his wife and his queen, Herod determines that she must die for her disobedience:

She's unchaste;

Her mouth will ope to ev'ry stranger's ear.

Then let the executioner make haste.

Lest she enchant him if her words he hear.

Let him be deaf, lest she do him surprise.

(Cary 2002, 4.7.77-81)

Mariam, who along with everyone else at the beginning of the play, mistakenly believes Herod to be dead, harbors a bitter anger toward the king, her husband, both for having married her primarily in order to gain access to the throne on which he now sits, and for having killed her relatives during his climb to power:

For Aristobulus, the lowliest youth

That ever did in angel's shape appear,

The cruel Herod was not moved to ruth;

Then why grieves Mariam Herod's death to hear?

Why joy I not the tongue no more shall speak,

That yielded forth my brother's latest doom:

Both youth and beauty might thy fury break,

And both in him did ill befit a tomb.

And, worthy grandsire, ill did he requite

His high ascent, alone by thee procured,

Except he murdered thee to free the sprite

Which still he thought on earth too long immured.

(Cary 2002, 1.1.35-46)

Despite her anger, she is torn over Herod's "death," vacillating between anger and nostalgia while remembering the times when she had loved him, or thought she had: "These thoughts have power, his death to make me bear, /Nay more, to wish the news may firmly hold: /Yet cannot this repulse some falling tear, /That will against my will some grief unfold. / And more I owe him for his love to me, /The deepest love that ever yet was seen" (Cary 2002, 1.1.51-56). But on finding that Herod is alive, and being brought to him due to his impassioned desire to see her- "The thought of Mariam doth so steal my sprite, / My mouth from speech of her I cannot wean" (Cary 2002, 4.2.43-44)-her anger overwhelms her; she refuses his bed, and berates him for the killing of her family, while rejecting the explanations he gives, which as Barbara Lewalski has observed, merely reinforces Herod's "jealous conviction that she has been unfaithful with Sohemus" (Lewalski 1993, p. 195), the king's counselor in whom Mariam had confided her anger and grief. Betrayed in a court intrigue by Salome, the sister of Herod who plays an Iago-like role in stoking Herod's jealousy, Mariam goes to her death, framed for a poisoning attempt she had no knowledge of, while naively trusting in her own innocence as a defense. She dies, in part, for asserting her will, for refusing to pretend any longer to love a man she now hates: "My lord, I suit my garment to my mind, / And there no cheerful colors can I find" (Cary 2002, 4.3.5-6).

The Chorus of the play, a body that Sandra Fischer describes as "traditional, almost reactionary in its observations, and certainly not to be heard as the voice of the playwright" (Fischer 1985, p. 236), 
blames Mariam for having been disobedient. For the Chorus, despite the fact that Mariam has not been physically unfaithful to Herod, she has been mentally or emotionally so through her confiding in Sohemus, and therefore has brought her execution on herself. The orthodox voice of the Chorus, that voice that always seems to stand for authority and against individual will, here suggests that Mariam should have been as her husband and owner, as her society and time would have desired her to be, a creature bound, restricted, and willingly so. Nor, according to the Chorus, is it enough to be obedient; one must also seem obedient in even the smallest of things, while preferring restraint and submission to freedom:

'Tis not enough for one that is a wife

To keep her spotless from an act of ill:

But from suspicion she should free her life,

And bare herself of power as well as will.

'Tis not so glorious for her to be free,

As by her proper self restrained to be.

(Cary 2002, 3 Chorus, 11. 1-6)

Mariam's lack of restraint, according to the Chorus, led her to take actions that, while not unlawful, were unwise. Confiding in Sohemus, and having been known to do so, is part of what plants suspicion in the mind of the jealous Herod. And for the Chorus, this is not Herod's problem, but Mariam's:

When she hath spacious ground to walk upon,

Why on the ridge should she desire to go?

It is no glory to forbear alone

Those things that may her honor overthrow.

But 'tis thankworthy if she will not take

All lawful liberties for honor's sake.

That wife her hand against her fame doth rear,

That more than to her lord alone will give

A private word to any second ear,

And though she may with reputation live,

Yet though most chaste, she doth her glory blot,

And wounds her honor, though she kills it not.

(Cary 2002, 3 Chorus, 11. 7-18)

Why walk right up to the line of allowable behavior and attitudes, the Chorus asks. Why not restrain yourself, tighten those mind-forg'd manacles even more tightly than one's rulers would have you do, just to be extra sure of being compliant, and cheerfully so at that? And to talk, to converse, to open one's most private thoughts and doubts to anyone other than one's husband, one's private ruler, well, how can you not see that as a "blot," a wound to one's "honor," an insidious and subtle form of disobedience? For the Chorus, the proposition that a woman is wholly owned-in body and mind, action and thought-is self-evident:

When to their husbands they themselves do bind,

Do they not wholly give themselves away?

Or give they but their body, not their mind,

Reserving that, though best, for others' prey?

No sure, their thoughts no more can be their own,

And therefore should to none but one be known.

Then she usurps upon another's right,

That seeks to be by public language graced:

And though her thoughts reflect with purest light,

Her mind if not peculiar is not chaste. 
For in a wife it is no worse to find,

A common body than a common mind.

(Cary 2002, 3 Chorus, 11. 19-30)

The Chorus, though acknowledging Mariam's innocence, nevertheless blames her for her eventual death, because she did not keep herself a strict and exclusive possession of Herod's. Had only Mariam done so, in demonstration of the "fact" that married women's "thoughts no more can be their own" because they are entirely owned by their husbandly lords and masters who require absolute obedience in both action and thought, then Mariam had "[b]een free from fear, as well as innocent" (Cary 2002, 3 Chorus, 1. 36). A more thoroughgoing description, not of mere authoritarianism, but of totalitarianism, will not come along again in English literature until Orwell:

You are here because you have failed in humility, in self-discipline. You would not make the act of submission which is the price of sanity. [...] The Party is not interested in the overt act: the thought is all we care about. [...] We are not content with negative obedience, nor even with the most abject submission. When finally you surrender to us, it must be of your own free will. [...] It is intolerable to us that an erroneous thought should exist anywhere in the world, however secret and powerless it may be. (Orwell 1961, pp. 205, 209, 210)

In a world that insists on obedience, on willed and cheerful submission, the one who refuses, who says non serviam to those who take pleasure in being obeyed, is often cast into the role of villain. Such is the case in The Tragedy of Mariam with the character Salome. Lewalski calls her "[t]horoughly wicked," and remarks that "she will do anything to compass her own will," including flaunting "her illicit affairs and [having] "two husbands killed when she is ready to replace them" (Lewalski 1993, p. 196). Lewalski goes on to assure us that "[m]ost readers of the age would share [her not-yet dead husband's] view that his wife's 'private conference' with her new lover Sileus is shameful," but that most of all, "her proposal to divorce her husband is shocking-a gender confusion that threatens order in nature and society" (Lewalski 1993, pp. 196-97). Lewalski is at least partly right, even though her rush to moral judgment prevents her from giving more than a glancing consideration to the truly radical nature of Salome's proposal. As Ilona Bell notes, "Salome expressly repudiates Judaic law, which gives men but not women the right to divorce" (Bell 2006, p. 24).

But Salome is no mere villain. She is this play's most powerful embodiment of carpe diem's insistence on the freedom to choose how to live and whom to love. Through Salome, Elizabeth Cary attacks one of the most basic structural inequities (and iniquities) of Renaissance England: the near-ownership of wives by husbands, and the inability of wives yoked to neglectful, unfaithful, financially profligate, and even violent husbands to find any relief from either the church or the crown:

Cary's Judaic Palestine resembles early modern England insofar as English common law granted legal rights to husbands that it did not officially grant to wives, and those rights granted to husbands gave them significant economic powers over their wives. The result was a system in which husbands' potential abuse of their legal rights might place wives in vulnerable positions. Cary's Mosaic law, therefore, stands in for Renaissance English marriage law. (Alfar 2008, p. 62)

There is no record of Cary's drama ever having been performed, as Andrew Hiscock has noted, but as a play designed to be read, it was equally designed to stir emotional controversy and intellectual debate:

There is no evidence that Mariam was ever publicly staged in early modern England, and the fact that the play was composed within the conventions of closet drama makes this possibility all the more unlikely. This kind of composition, influenced by Senecan and French Renaissance tragic modes of writing, [...] overtly foregrounded intellectual and cultural 
debate, stressing the exploration of political doctrine and dissent. It was seen primarily as a reading experience which privileged discussion over dramatization, the word over the deed. (Hiscock 2004, p. 118)

Debate, discussion, and dissent revolve around the character of Salome, who serves Cary in much the same way that Iago and Edmund serve Shakespeare, as a means for expressing sentiments and giving voice to ideas radically outside the mainstream in England: "Salome apostrophizes herself, 'ill-fated Salome,' because like Iago or Edmund, she aims to be the agent of her own fate" (Bell 2006, p. 25). In a time and place in which English Protestants were enmeshed within a theology that was a blend of Luther's notion of the bondage of the will, and Calvin's insistence that the human will was entirely depraved and corrupted by sin, to assert freedom of the will was tantamount to denying the power of God, and in practical terms, declaring oneself an atheist.

For the twin giants of Reformation theology, fallen man was inherently worthy of damnation; all deserved the most severe and horrible judgment, but some-quite undeservedly-would be given the gift of God's grace. Luther expresses the full force of this idea in his De Servo Arbitrio (The Bondage of the Will): "Because there is none righteous, no, not one is aware, no one who seeks God, all have turned aside, they are together become unprofitable, there is none that does good, no, not one." ${ }^{10}$ For Luther, human will is inherently evil, and is only able to "choose" evil (thus making a mockery of choice) unless it is bolstered by the grace of God. Only by God's grace can a human being choose the good. Calvin expresses a similar idea: "mankind is so captured by the yoke of sin that he cannot aspire to the good in his actions or in his will."11

Now Cary was not an atheist, but neither was she much impressed with the theological stylings of Luther and Calvin; much of her life was spent struggling, with herself and others, over her rejection of such theological ideas in her conversion to Catholicism. However, in the face of what Alfar calls "patrilineal injunctions for appropriate female identity" (Alfar 2008, p. 89), and in the face of an England in which women were trapped by what Laura Gowing calls "a uniquely unreformed canon law on marriage" 12 such necessary criticisms as Cary makes in The Tragedy of Mariam are most safely made through a character in relation to which one can claim a certain level of Nixonian "plausible deniability." Oh, that was the villain talking. You can't take that seriously. But just as with the calls to choose life and love now in carpe diem poetry, Salome's critique, embodied in her choice to love whom she desires and when she desires, must be taken seriously.

For what Salome does is to tear the traditional claims of male privilege-and their hypocritically pious bases in religion-absolutely to shreds. In her view, it is intolerable that men can choose but women can only be chosen, that men can reject but women can only be rejected, and that under the Mosaic law married men may divorce but married women are owned for life. Salome loves Sileus, and would choose to be with him, except that the demands of authority, law, and religion would have her believe that such a choice is not possible. But Salome no longer believes in the laws and pieties of her island and tribe, and instead subjects those laws and pieties to a devastating critique:

But shame is gone, and honor wiped away,

And impudency on my forehead sits:

She bids me work my will without delay,

And for my will I will employ my wits.

He loves, I love; what then can be the cause

10 "Quia non est justus quisquam, non est inteligens, non est requirens Deum, omnes declinaverunt, simul inutiles facti funt, non est qui faciat bonum, non est usque ad unum" (Luther 1707, p. 195).

11 "Hominen peccati iugo ita captium teneri, ne ad bonum aut voto aspirare" (Calvin 1559, p. 101).

12 Gowing explains that "while Protestant states in Europe were moving towards separations which allowed at least the innocent party to remarry, England's church courts remained empowered to do no more than grant judicial separations, 'from bed and board.' Such separations allowed couples to live apart, but precluded remarriage by either party, guilty or innocent" (Gowing 1996, pp. 180-81). 
Keeps me from being the Arabian's wife?

It is the principles of Moses' laws,

For Constabarus still remains in life.

(Cary 2002, 1.4.33-40)

As Alfar notes, Salome's "marriage to Constabarus stands in the way of her wish to marry the Arabian prince, Silleus." But instead of simply submit to the demands of law, or as Mariam does, rebel inwardly while maintaining an outward appearance of conformity, Salome rejects the "unequal distribution of legal rights that tie her unwillingly to a man she no longer loves" while going on to target the primary source of injustice, "the inequity between men and women in Mosaic law that bars women from divorcing their husbands while allowing husbands to divorce their wives" (Alfar 2008, p. 62):

If he to me did bear as earnest hate,

As I to him, for him there were an ease;

A separating bill might free his fate

From such a yoke that did so much displease.

Why should such privilege to man be given?

Or given to them, why barred from women then?

Are men than we in greater grace with Heaven?

Or cannot women hate as well as men?

I'll be the custom-breaker: and begin

To show my sex the way to freedom's door,

And with an off'ring will I purge my sin;

The law was made for none but who are poor.

(Cary 2002, 1.4.41-52)

Taking on, in the last line quoted above, something of the voice of Shakespeare's Richard III, for whom "Conscience is but a word that cowards use, /Devised at first to keep the strong in awe" (Richard III, 5.3.310-11). Salome stands up and takes her place within a fellowship of like-minded characters in early modern literature, devotees of the religion of Will, literary creations that might be called "Apostles of the Will," who think of themselves as individuals, not determined by their worlds, but remaking them in their own images, male and female, old and young. Such characters believe in a thing we have come to call "Free Will," and think themselves entitled to live as they choose, to fashion their lives, their worlds, their very selves in the image of their desires.

What is most powerfully relevant about such characters as Salome is not that they choose for good or for ill, but that they choose. Especially in a world in which authority is often considered to be divinely-sanctioned, to resist that authority can be seen as diabolically radical. For Cary to write such a character, inhabiting a play that problematizes the authority of husbands and kings by showing that authority to be jealous and tyrannical, is easily understood as a radical act. In fact, as Alfar points out, it is a critique of the very foundations of an authoritarian society:

When Cary writes a play whose wives struggle with and call into question their obedience to their husbands and their relationship to marriage law, and when one of these husbands is a king and a tyrant, largely because of his misuse of marriage law, [she] launches a simultaneous critique against orthodox forms of marriage and monarchy, for the absolute authority of kings and husbands makes of both institutions a tyranny against which married women have little recourse. (Alfar 2008, p. 67)

What Salome stands up for, despite her betrayal of Mariam (which does not discredit the political stand she takes on marriage, unless one is casting about for even thinly plausible reasons to reject that stand), is the idea that the freedom to choose whom to love, how to love, if to love is not one that can be ceded to the demands of kings, laws, and customs without a fight: she fights not only for her own interests (as a critic determined to poke holes in her arguments might insist), but also for the interests 
of all women (and by extension, all those of any gender or definition who find themselves subject to the authority of tyrants).

In struggling "[t]o show [her] sex the way to freedom's door," Salome also struggles on behalf of characters like Pheroras, who has been ordered by Herod to marry a woman he does not love, one whom he describes as "a baby" and related to him within the degrees of consanguinity that would comprise incest: "What though she be my niece, a princess born? /Near blood's without respect, high birth a toy, /Since love can teach us blood and kindred's scorn" (Cary 2002, 2.1.16, 22-24). Pheroras would choose (and is chosen by) Graphina, but as this play's version of the "star-crossed lovers," their ability to choose has been overridden by the demands of authority. Bell explains this dynamic cogently within its poetic context:

Like Donne's lovers, whose 'true plain hearts do in the faces rest' ('The Good Morrow'), Pheroras treats Graphina as another desiring subject who shares his liberation and returns his loving gaze: 'This blessed hour ... hath my wished liberty restor'd, / And made my subject self my own again. /Thy love, fair maid, upon mine eye doth sit' (2.1.6; 9). By contrast, Salome represents herself as desiring subject ('When I on Constabarus first did gaze'), but reduces her lover to the mirror of her desires, rendering him the 'object to mine eye' (1.4.275). Like the traditional Petrarchan poet, Salome assumes that the whole world shares her admiration for her beloved's physical beauty: 'Whose looks and personage must [all eyes] amaze' (1.4.276). Sileus is perfectly willing to be objectified and controlled by Salome; he is pleased to be 'deified, /by gaining thee' (1.4.327). (Bell 2006, p. 24)

Cary is striving to make a point, disguised though it might be behind the overt villainy of Salome as the struggler for choice in love, for as Erin Kelly tells us, "Cary's most wholly original addition to the story of Mariam and Herod [is] the character Graphina" (Kelly 2006, p. 40). In this addition, one that seems deliberately calculated in order to enhance the theme of love chosen despite authority, the theme of injustice and immorality is not focused on so obvious a target as Salome, but as Alfar argues, on the "tyrannical system of marriage and monarchical relations that the play depicts as immoral" (Alfar 2008, p. 90).

Against such views as those expressed by Constabarus, for whom women are merely and properly property, Salome stands up for the right and ability to choose one's own love and life, and is more than willing to engage her Machiavellian side to fight for that right and ability. Those readers who would have her be as Mariam is, or who would have both characters be as meek and mild as Graphina, would seem to choose an outward morality over an inward freedom. The seemingly moral are often the most immoral in Cary's play. Constabarus, for example, who stands up for the traditional monarchical and hierarchical order, sounds a great deal like Shakespeare's Ulysses, the great liar and manipulator from Troilus and Cressida while so doing:

Are Hebrew women now transformed to men?

Why do you not as well our battles fight,

And wear our armor? Suffer this, and then

Let all the world be topsy-turvèd quite. turned upside down

Let fishes graze, beasts swim and birds descend,

Let fire burn downwards whilst the earth aspires:

Let winter's heat and summer's cold offend,

Let thistles grow on vines, and grapes on briars,

Set us to spin or sew, or at the best

Make us wood-hewers, water-bearing wights:

For sacred service let us take no rest,

Use us as Joshua did the Gibonites.

(Cary 2002, 1.6.47-59) 
For Constabarus, as Alfar argues, "[w]hat makes Salome evil [...] and earns her [his] vitriolic condemnation is her appropriation of men's legal privileges, which he sees as a breach of a natural gender divide" (Alfar 2008, p. 85). The structure of the world depends, in Constabarus' view, on Salome's obedience to a system of laws that gives him a structural advantage while requiring that she "wholly give herself away" in the words of the Chorus. Similarly, Shakespeare's Ulysses argues for the absolute necessity of other people's obedience in maintaining the "proper" order of the universe:

$\mathrm{O}$, when degree is shaked,

Which is the ladder to all high designs,

Then enterprise is sick! How could communities,

Degrees in schools and brotherhoods in cities,

Peaceful commerce from dividable shores,

The primogenitive and due of birth,

Prerogative of age, crowns, sceptres, laurels,

But by degree, stand in authentic place?

Take but degree away, untune that string,

And, hark, what discord follows!

(Troilus and Cressida, 1.3.101-10)

Such an exhortation to order is especially rich coming from Ulysses, famous in Greek and Roman literature for his virtuosic facility with lying and self-serving deceit. But then, as Bell reminds us, a sense of the shared hypocrisy of Constabarus and Ulysses is probably part of the effect Cary's text is trying to achieve:

On the surface, Constabarus is a "good" character, the upholder of morality and social order. He cherishes Mariam's virtue and wishes to protect her from Salome. He loves Salome despite her infidelity, and tries to protect her from herself: "My words were all intended for thy good, /To raise thine honour and to stop disgrace" (1.6.411-12). Yet Constabarus's sermonizing begins to look considerably less high-minded and more suspiciously self serving when we recall, first, that his goal is to get Salome (with her access to networks of power) back, subdued to his will and his gain; and, second, that his own love for Salome began as an adulterous liaison (Salome was then married to Josephus). When Constabarus's speech and the scene end with another sonnet extolling the "sweet-fac'd," "innocent," "purest" Mariam, it becomes increasingly clear that Constabarus admires and idealizes Mariam as the ideal of female virtue precisely because he sees her as powerless. (Bell 2006, p. 26)

In the world of power, with its brutal demands for obedience (especially from women who are idealized for their lack of power), and its calls for compliance even at the level of thought, it is love-not plotting and villainy-that is the energy and the engine that enables resistance. As Bell argues, the power of love is what drives the rebellions described in the play:

Like Pheroras and Graphina, Salome and Sileus enjoy a fully mutual love: 'He loves, I love; what then can be the cause/Keeps me [from] being the Arabian's wife?' (1.4.297-98). Like many Elizabethan poets/lovers (including Sidney, Donne, Gascoigne, Whythorne, and Daniel) who used enigmatic, allegorical poetry to negotiate clandestine marriage contracts or extramarital love affairs, Salome urges her lover, Sileus, to join her in rejecting the social, ethical, and legal codes that would prevent them from fulfilling their desires. (Bell 2006, p. 24)

\section{Conclusions}

There is sometimes a tendency among literary critics to downplay the subversive elements in such work as Marvell's and Cary's. Marvell's poem, as Nigel Smith argues, "is a parody of the Christian doctrine of resurrection: death is overcome not by resurrection in the afterlife but by life" (Smith 2010, 
p. 106). However, Smith quickly retreats into the more orthodox suggestion that Marvell is merely being ironic: "the speaker thinks that lust will be rewarded with more pleasure in life; the Christian knows that the wages of sin (i.e., lust) are death" (Smith 2010, p. 106). Perhaps. But what the carpe diem ethos has asked of readers since the time of Horace is to see that the wages of life are death, and no amount of obedient dismissal of one's own desires, no quantity of choice given over to those in authority, will lessen the payment when it finally comes due.

To reject the subversive message of Marvell's poem is to miss the extent of its power. To vilify the voice of Cary's character Salome-merely giving it a kind of "devil's due" while burying that voice and its claims inside the critical rhetoric of wickedness and claims about what " $[\mathrm{m}]$ ost readers of the age" (Lewalski 1993, p. 196) would have thought of her-is to miss the depth and vigor of its critique. This is akin to the reductive gesture Lawrence Stone makes with Shakespeare-treating a literary artifact as limited by the conditions of its time and place, while regarding those conditions as monolithic and without exceptions or currents of resistance. ${ }^{13}$ Kiernan Ryan has long argued that such critical stances do a great injustice to the potential of literature to "dramatise the future possibilities stored in stubborn actualities" (Ryan 1995, p. 39).

A voice like Salome's is richer and more textured for its engagement with the very same carpe diem ethos that Marvell's poem itself engages with some decades later. In calling for "His Coy Mistress" to choose life and love in the here and now, Marvell's poetic voice stands in a millennia-long tradition of resistance to authority. In calling for freedom against tyranny, for choice in love and marriage, and for the ability to live on one's own terms, despite the demands of those whose imperious wills simply must be obeyed, Elizabeth Cary's Salome transcends the role of a mere villain. In so doing, she becomes not just an Apostle of the Will, but an Apostle of Choice, and a powerful embodiment of the ethos of carpe diem poetry.

Funding: This research received no external funding.

Conflicts of Interest: The author declares no conflict of interest.

\section{References}

Alfar, Cristina León. 2008. Elizabeth Cary's Female Trinity: Breaking Custom with Mosaic Law in 'The Tragedy of Mariam'. Early Modern Women 3: 61-103.

Anderson, Linda. 1991. The Nature of Marvell's Mower. Studies in English Literature 31: 131-46. [CrossRef]

Ausonius. 2001. Ausonius: Epigrams. Text with Introduction and Commentary. Edited by Nigel M. Kay. London: Duckworth.

Bell, Ilona. 2006. Private Lyrics in Elizabeth Cary's Tragedy of Mariam. In The Literary Career and Legacy of Elizabeth Cary. Edited by Heather Wolfe. Gordonsville: Palgrave Macmillan, pp. 17-34.

Belsey, Catherine. 1987. Love and Death in 'To His Coy Mistress'. In Post-structuralist Readings of English Poetry. Edited by Richard Machin and Christopher Norris. Cambridge: Cambridge University Press, pp. 105-21.

Blake, William. 1893. The Works of William Blake. Edited by Edwin John Ellis and William Butler Yeats. London: Benard Quartich, vols. 1-3.

Calvin, Jean. 1559. Institutio Christianae Religionis. Genevae: Oliua Roberti Stephani.

Cary, Elizabeth. 2002. The Tragedy of Mariam. In English Renaissance Drama. Edited by David M. Bevington, Lars Engle and Katharine Eisaman Maus. New York: W.W. Norton.

Davis, Philip J. 1999. Ovid's Amores: A Political Reading. Classical Philology 94: 431-49. [CrossRef]

13 Stone argues that "the tragedy of Romeo and Juliet, [lay] in the way they brought destruction upon themselves by violating the norms of the society in which they lived," and frames Shakespeare's plays in terms of "a clear conflict of values between the idealization of love by some poets, playwrights and the authors of romances on the one hand, and its rejection as a form of imprudent folly and even madness by all theologians, moralists, authors of manuals of conduct, and parents and adults in general" (Stone 1977, pp. 87, 181). For Neema Parvini, such a perspective indicates "how entrenched and pervasive the cultural historicist view [has] become," and reflects "a form of social determinism [in which individuals] are said to be conditioned by a set of social, cultural and ideological forces," and are regarded as "entirely products of their particular place at a particular historical moment" (Parvini 2012, pp. 2, 52). 
Douglass, Frederick. 2000. West India Emancipation. In Frederick Douglass: Selected Speeches and Writings. Edited by Philip S. Foner and Yuval Taylor. Chicago: Chicago Review Press, pp. 358-68.

Duyfhuizen, Bernard. 1988. Textual Harassment of Marvell's Coy Mistress: The Institutionalization of Masculine Criticism. College English 50: 411-23. [CrossRef]

Emerson, Ralph Waldo. 2002. Self Reliance. In Nature and Selected Essays. Edited by Larzer Ziff. London: Penguin, pp. 175-204.

Fischer, Sandra K. 1985. Elizabeth Cary and Tyranny. In Silent But for the Word: Tudor Women as Patrons, Translators, and Writers of Religious Works. Edited by Margaret P. Hannay. Kent: Kent State University Press, pp. $225-37$.

Gide, André. 1921. Les Nourritures Terrestres. Paris: Gallimard.

Glancy, Ruth F. 2002. Thematic Guide to British Poetry. Westport: Greenwood Press.

Gowing, Laura. 1996. Domestic Dangers: Women, Words, and Sex in Early Modern London. Oxford: Clarendon. Oxford: Clarendon.

Hiscock, Andrew. 2004. The Uses of This World Thinking Space in Shakespeare, Marlowe, Cary, and Jonson. Cardiff: University of Wales Press.

Horace, Daniel H. Garrison. 1998. Horace: Epodes and Odes. Edited by Daniel H. Garrison. Norman: University of Oklahoma Press.

Kelly, Erin E. 2006. Mariam and Early Modern Discourses of Martyrdom. In The Literary Career and Legacy of Elizabeth Cary. Edited by Heather Wolfe. Gordonsville: Palgrave Macmillan, pp. 35-52.

Lewalski, Barbara. 1993. Writing Women in Jacobean England. Cambridge: Harvard University Press.

Luther, Martin. 1707. B. Patris Martini Lutheri Liber de Servo Arbitrio. Edited by Sebastian Schmid. Strasburg: J. R. Dulsseckeri.

Marvell, Andrew. 2003. The Poems of Andrew Marvell. Edited by Nigel Smith. London: Pearson.

Milton, John. 1957. Complete Poems and Major Prose. Edited by Merritt Hughes. New York: Odyssey Press.

Moldenhauer, Joseph J. 1968. The Voices of Seduction in 'To His Coy Mistress': A Rhetorical Analysis. Texas Studies in Literature and Language 10: 189-206.

Musil, Robert. 1957. Der Mann Ohne Eigenschaften [The Man without Qualities]. Berlin: Rowohlt Verlag.

Orwell, George. 1961. 1984. New York: Signet.

Parvini, Neema. 2012. Shakespeare's History Plays: Rethinking Historicism. Edinburgh: Edinburgh University Press. Rudolph, Wilhelm, and Karl Elliger. 1983. Biblia Hebraica Stuttgartensia. Edited by Karl Elliger and Willhelm Rudolph. Stuttgart: Deutsche Bibelgesellschaft.

Ryan, Kiernan. 1995. Shakespeare, 2nd ed. Hempsted: Prentice Hall.

Schiller, Friedrich. 1873. Gedichte von Friedrich von Schiller. Stuttgart: J.G. Cottaschen Buchhandlung.

Shakespeare, William. 2002. William Shakespeare: The Complete Works. Edited by Stephen Orgel and A.R. Braunmuller. New York: Pelican.

Smith, Nigel. 2010. Andrew Marvell: The Chameleon. New Haven and London: Yale University Press. Stone, Lawrence. 1977. The Family, Sex, and Marriage in England 1500-1800. New York: Harper and Row. Wheeler, Thomas. 1996. Andrew Marvell Revisited. New York: Twayne Publishers.

(C) 2018 by the author. Licensee MDPI, Basel, Switzerland. This article is an open access article distributed under the terms and conditions of the Creative Commons Attribution (CC BY) license (http://creativecommons.org/licenses/by/4.0/). 